\title{
Functional properties change of Nagara bean flour through fermentation by lactobacillus plantarum
}

\author{
*Susi Susi ${ }^{1}$, Lya Agustina' dan Condro Wibowo² \\ ${ }^{1}$ Department of Agroindustrial Technology, Lambung Mangkurat University Banjarbaru South Kalimantan, Indonesia \\ ${ }^{2}$ Department of Food Science and Technology, Jenderal Soedirman University, Purwokerto, Central Java Indonesia \\ *Corresponding Author Email: susi tip@unlam.ac.id
}

\begin{abstract}
Nagara bean (Vigna Unguiculata ssp. Cylindrica) is one of cowpea subspecies which has a high carbohydrate content of $50-60 \%$ and $20-25 \%$ protein. In order to increase flour products of Nagara cowpea, its functional properties can be improved through fermentation by using Lactobacillus plantarum. This research was examined functional properties changes of Nagara bean flour fermented by $L$. plantarum from 24 to 120 hours using their size variation of a whole and grits bean. The best result of degree of water absorption, swelling volume and gelatinization of cowpea flour were showed along 48 hours fermentation and grits size with $198.29 \%$ level of water absorption db, peak viscosity of $2500 \mathrm{cP}$ and final viscosity of $2500 \mathrm{cP}$ respectively.
\end{abstract}

Keywords : Nagara bean, water absorption, swelling volume, solubility, gelatinization profile

\section{INTRODUCTION}

Nagara bean (Vigna unguiculata ssp.Cylindrica) is a local cowpea grown in South Kalimantan and well adapted both in dry lands and lowland swamps. Olapade et al. (2012) stated that cowpea contained a high carbohydrate of $50-60 \%$ and $20-25 \%$ of protein with dominant amino acids classified as arginine, isoleusine, glutamate and aspartate (Tangadurai, 2005). Susi (2012) researched that dominant essential amino acids of cowpea were $0.734 \%$ valine, $0.791 \%$ metionine and $0.775 \%$ phenilalanine; and dominant non essential amino acids were $0.913 \%$ aspartic acid, $2.182 \%$ glutamic acid and $0.826 \%$ histidine. Moreover, nutrient of cowpea was suitable for people who were not consuming meat and fish (Atuobi et al. 2011).

The useful of Nagara bean in Kalimantan is limited only for additional food in cooking. Increase of Nagara bean use can be achieved by knowing functional properties of Nagara bean flour. Niba (2003) reported limitation of legume characteristics could be improved by applying bioprocess and fermentation technique. This bean has anti nutrients consisted of $1.9 \mathrm{~g} / 100 \mathrm{~g}$ total phenolic compound and $5.6 \mathrm{~g} / 100 \mathrm{~g}$ tannin (Thangadurai 2005). Fermentation technique is usually used for improving quality of starch such as structure modification, physical and chemical characteristics (Chinsamran et al. 2005), whereas this technique influences solubility properties, swelling volume and flour viscosity of products used for next processing.

The research aimed to examine functional properties of Nagara bean flour through fermentation processes by Lactobacillus plantarum using variation in periods fermentation and in grain size. Lactic acid bacteria like $L$. plantarum functions as fermentation agents of flour to modify the functional characteristics. These bacteria classified as Amilolitic-Lactic Acid Bacteria have a capability to degrade flour both in direct ways and in facultative hetero-fermentative methods. The functional characteristics of Nagara bean were investigated degree of water absorption, swelling volumes and gelatinization profiles.

\section{MATERIALS AND METHODS}

\section{Materials}

Nagara bean was originated in Nagara - Hulu Sungai Selatan district of South Kalimantan. A water bath 
shaker, a centrifuge, an oven and a glassware were used in the research.

\section{Spontaneous Fermentation Process}

A total of fermentation using Lactic Acid Bacteria $L$. plantarum was $1 \%(\mathrm{v} / \mathrm{v})$ with the size of bean were a whole grain and grits. The ratio of Nagara bean and water soaking was one fourth with different fermentation periods for instance 24, 48, 72, 96 and 120 hours. Soon after fermentation, Nagara bean was rinsed and peeled and then dried in $60^{\circ} \mathrm{C}$ for 48 hours. Next, the bean was floured for 80 mesh.

Data analysis was done for water absorption, swelling volume, solubility and gelatinization profile by using Rapid Visco Analyzer Model RVA-S4 with the Thermocline for Windows (TWC) program. In addition, granular characteristics were examined by Scanning Electron Microscopy (SEM).

\section{Water Absorption Capacity by gravimeters}

A centrifugal tube was filled $2 \mathrm{~g}$ flour (a) and added distilled water and spun with a vortex. After that, the sample was waited for 30 minutes and centrifuged with the speed $3000 \mathrm{rpm}$ for 15 minutes, and stored in the desiccators then weighed (b).

Water Absorption Capacity (\%db)

Water absorption capacity $(\% d b)=\frac{b-a}{m s} \times \frac{100 \%}{(1-k a)}$ , whereas

$\mathrm{a}=$ dried sample + centrifugal tube $(\mathrm{g})$

$\mathrm{b}=$ wet sample + centrifugal tube $(\mathrm{g})$

$\mathrm{ms}=$ sample $(\mathrm{g})$

\section{Solubility dan Swelling volume}

Swelling volume was examined by weighting $0.35 \mathrm{~g}$ of flour and added $12.5 \mathrm{~mL}$ water and placed in a centrifugal tube. After that, the sample was spun by a vortex and placed in waterbath for $92.5^{\circ} \mathrm{C}$ and then every 5 minutes was vortexed for 10 minutes. The sample was cooled in an ice for 1 minutes and warmed $25^{\circ} \mathrm{C}$ for 15 minutes. Then, the sample was centrifuged for $3600 \mathrm{rpm}$ for 15 minutes. The volume of formed gel was measured (swelling volume) in $\mathrm{mL} / \mathrm{g}(\mathrm{db})$. The solubility was formed by pouring supernatant to weighted cup and then dried for $110^{\circ} \mathrm{C}$ overnight.

Solubility $=\frac{w l}{w d m} \times 100 \%$

Swelling volume $(\mathrm{ml} / \mathrm{g} b \mathrm{k})=\frac{w 2}{w d m} \times 100 \%$ whereas

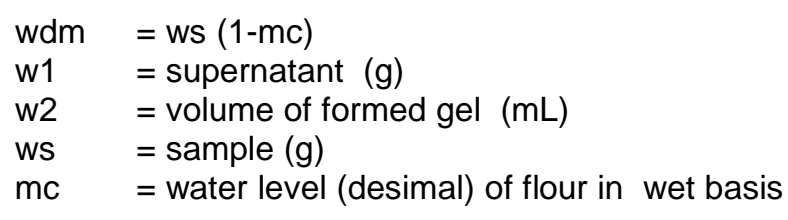

\section{RESULTS AND DISCUSSION}

\section{Water Absorption Capacity}

Granular starch is the main component of flour which can swell in cool or hot water. In cool water, the capacity of water absorption is limited; however, when the starch is heated the formed energy can break hydrogen bonds causing the area of water absorption enlarges and increases its capacity.

Water absorption capacity of control (non fermented Nagara bean flour) was $151.45 \%$ and fermentative treatments could increase the capacity of water absorption. Analysis of variance $(\alpha=5 \%)$ showed the significant differences in fermentation periods to the capacity of water absorption of fermented Nagara bean flour. Table 1 explained water absorption of Nagara bean flour.

Water absorption of fermented Nagara bean indicated that an increase of water absorption was in line with fermentation periods until 120 hours for whole beans; nevertheless it was not affected by fermentation periods for 96 and 72 hours.

Another study reported that the activity of proteolytic microorganism influenced added polar groups of granular starch along fermentation processes and these groups could lift hydrophilic flour (Etudaiye et al. 2009).

\section{Swelling Volume}

A swelling volume reveals degree of swelling granular starch when interacts with water. The more water is absorbed, the increase of swelling granular starch happens. The percentage of swelling volume of non fermented Nagara bean flour was $590.48 \%$ and adding $L$. plantarum as a fermentative agent produced an increase of swelling volume. Analysis of variance $(\alpha=5 \%)$ noted that the single fermentation periods influenced swelling volume of flour. Table 1 illustrates the swelling volume.

A swelling volume of fermented Nagara bean flour by L. plantarum increased in fermentation periods for 72 hours both a whole bean and grits; however, it decreased after 72 hours of fermentation. Swelling volume of flour is usually related to protein and starch of flour. Along fermentation processes, Lactic Acid Bacteria (LAB) produce proteolytic enzymes functioning to degrade protein in Nagara bean. Moreover, LAB also produce amylase to degrade amylose, so amylose content 
Table 1. Water absorption, swelling volume and solubility of fermented Nagara bean flour by L. plantarum

\begin{tabular}{|c|c|c|c|c|c|}
\hline \multicolumn{3}{|c|}{ Treatments } & \multicolumn{3}{|l|}{ Parameters } \\
\hline Size & $\begin{array}{l}\text { Fermentation } \\
\text { (hours) }\end{array}$ & periods & Water absorption (\% db) & $\begin{array}{l}\text { Swelling volume } \\
(\% \mathrm{db})\end{array}$ & Solubility (\% db) \\
\hline \multirow{5}{*}{ Whole } & 24 & & $160.87 \pm 23.56^{\mathrm{a}}$ & $622.05 \pm 38.88^{b}$ & $24.67 \pm 0.17^{\mathrm{a}}$ \\
\hline & 48 & & $192.19 \pm 1.45^{\mathrm{b}}$ & $714.61 \pm 3.30^{c}$ & $7.76 \pm 1.47^{b}$ \\
\hline & 72 & & $211.58 \pm 8.01^{b c}$ & $662.79 \pm 73.74^{\mathrm{b}}$ & $5.54 \pm 0.94^{b}$ \\
\hline & 96 & & $211.38 \pm 1.08^{\mathrm{C}}$ & $614.93 \pm 44.46^{\mathrm{ab}}$ & $6.16 \pm 0.21^{b}$ \\
\hline & 120 & & $215.07 \pm 3.89^{c}$ & $567.33 \pm 99.72^{a}$ & $5.96 \pm 0.92^{b}$ \\
\hline \multirow{5}{*}{ Grits } & 24 & & $197.16 \pm 5.53$ & $712.35 \pm 55.43$ & $20.52 \pm 2.80$ \\
\hline & 48 & & $198.29 \pm 2.98$ & $739.79 \pm 5.18$ & $6.00 \pm 0.09$ \\
\hline & 72 & & $202.88 \pm 2.33$ & $646.06 \pm 33.35$ & $5.96 \pm 0.01$ \\
\hline & 96 & & $220.41 \pm 1.19$ & $623.34 \pm 17.08$ & $5.92 \pm 0.12$ \\
\hline & 120 & & $216.92 \pm 11.14$ & $586.28 \pm 87.72$ & $5.91 \pm 0.14$ \\
\hline
\end{tabular}

*: the same letter indicates duncan test which is not significantly different

Table 2. The gelatinization profiles of fermented Nagara bean flour

\begin{tabular}{|c|c|c|c|c|c|c|c|c|c|}
\hline \multicolumn{2}{|c|}{ Treatments } & \multicolumn{8}{|c|}{ Gelatinization profile of Nagara bean flour } \\
\hline Size & $\begin{array}{l}\text { Fermenta } \\
\text { tion time } \\
\text { (hours) }\end{array}$ & $\begin{array}{l}\text { Peak } \\
\text { visc } \\
(c P)\end{array}$ & $\begin{array}{l}\text { Trough } \\
\text { visc }(\mathrm{cP})\end{array}$ & $\begin{array}{l}\text { Breakdown } \\
\text { visc }(c P)\end{array}$ & $\begin{array}{l}\text { Final } \\
\text { Visc } \\
\text { (cP) }\end{array}$ & $\begin{array}{l}\text { Seat } \\
\text { back } \\
\text { visc } \\
\text { (cP) }\end{array}$ & $\begin{array}{l}\text { Peak } \\
\text { Time } \\
(\min )\end{array}$ & $\begin{array}{l}\text { Peak } \\
\text { Temp (ㄷ) }\end{array}$ & $\begin{array}{l}\text { Pasting } \\
\text { temp }(\stackrel{\circ}{ } \mathrm{C})\end{array}$ \\
\hline \multirow[t]{5}{*}{ Whole } & 24 & 1845 & 1137 & 708 & 1668 & 531 & 7.80 & 91.00 & 79.30 \\
\hline & 48 & 2453 & 1159 & 1294 & 2124 & 965 & 7.73 & 90.65 & 78.05 \\
\hline & 72 & 2633 & 1306 & 1327 & 2460 & 1154 & 7.93 & 91.85 & 77.70 \\
\hline & 96 & 2301 & 1163 & 1138 & 2284 & 1121 & 8.00 & 92.20 & 78.05 \\
\hline & 120 & 2349 & 1249 & 1100 & 2427 & 1178 & 8.33 & 94.20 & 78.85 \\
\hline \multirow[t]{5}{*}{ Grits } & 24 & 2322 & 1140 & 1182 & 2123 & 983 & 7.80 & 91.00 & 78.05 \\
\hline & 48 & 2722 & 1326 & 1396 & 2500 & 1174 & 7.87 & 91.45 & 78.10 \\
\hline & 72 & 2713 & 1322 & 1391 & 2650 & 1328 & 7.93 & 91.85 & 77.70 \\
\hline & 96 & 2438 & 1181 & 1257 & 2499 & 1318 & 8.13 & 92.95 & 78.50 \\
\hline & 120 & 2563 & 1299 & 1264 & 2906 & 1607 & 8.13 & 93.00 & 78.10 \\
\hline Control & & 2093 & 1074 & 1019 & 1617 & 543 & 7.53 & 89.30 & 78.10 \\
\hline
\end{tabular}

decreased. The low amylosa can enhance swelling volume of starch (Tester and Morisson, 1990). Leach et al. (1959) explained that swelling volume was influenced by granular bonding. LAB yielded amylase attacking amorphous area of starch, and then LAB hydrolytic performances were induced by both enzymes and organic acids produced in fermentation processes. Along heating processes, starch will gelatinize and the granule will swell and then another part of dissolved starch will influence level of viscosity. A rigid structure is difficult to swell due to a solid matrix causing limited water absorption.

\section{Solublility}

The solubility percentage of non fermented Nagara bean flour was $20.13 \%$ db whereas the soluble fermented Nagara bean flour tended to decrease together with an increase of fermentation periods by $L$. plantarum. The solubility is explained Table 1. Lactic acid bacteria produce cellulose enzymes degrading cellulose of starch cell walls and breaking cell walls, then, granular starch will leave contributing toward the in/outflow of water and amylosa in granular starch. Due to polar characters of amylosa, the solubility will enhance; 
128 Afr. J. Food Sci. Technol.

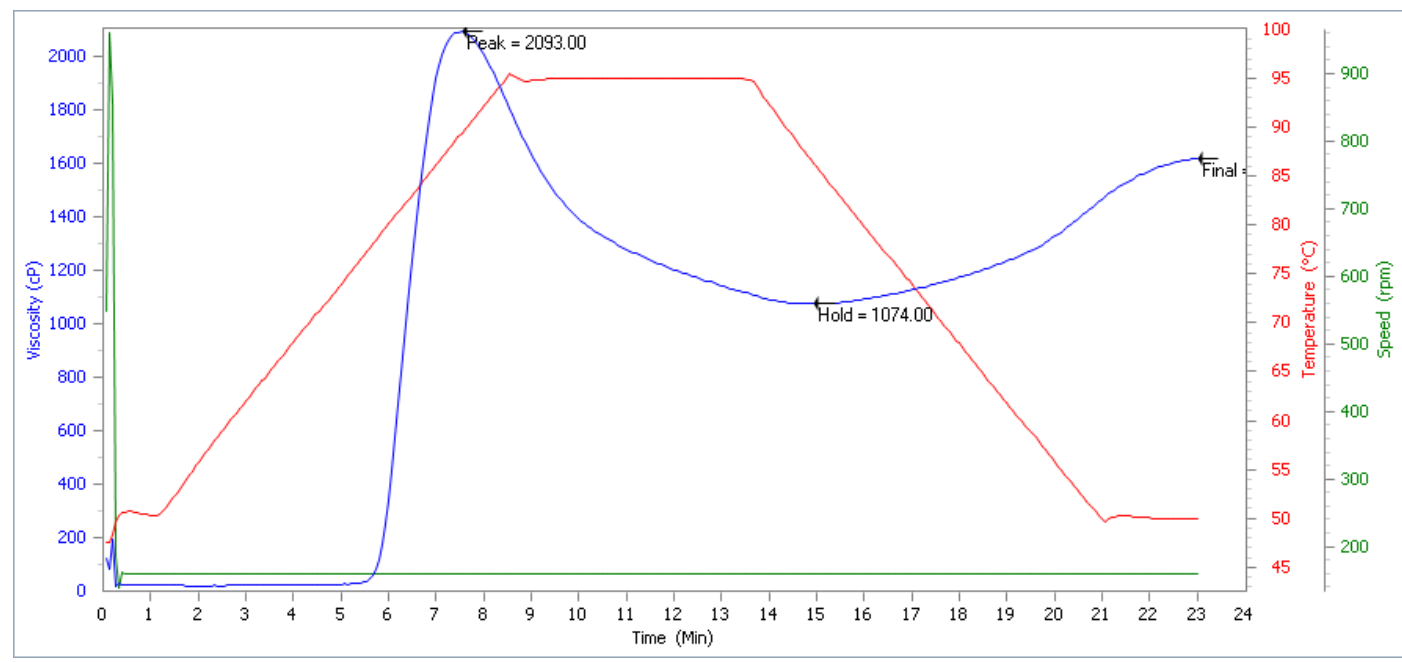

Figure 1. Gelatinization profiles of Nagara bean flour (control)

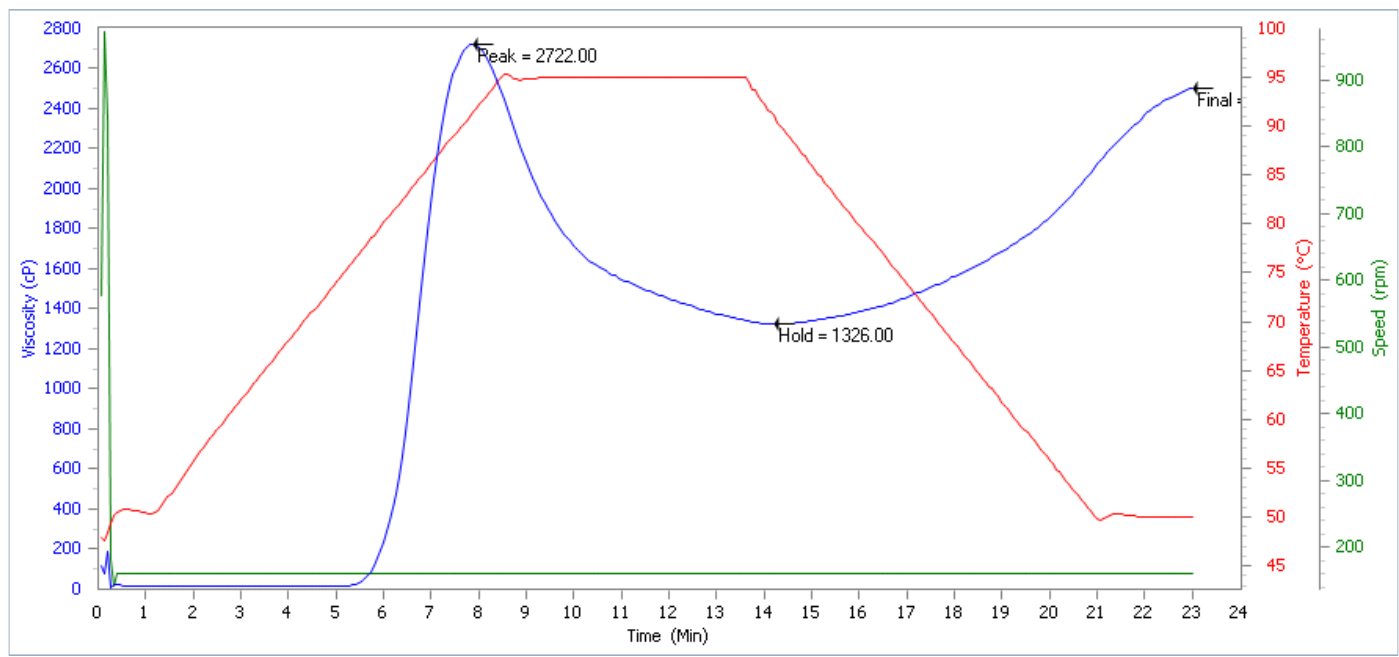

Figure 2. Gelatinization profiles of fermented Nagara bean flour using L. plantarum for 48 hours and grits sizes.

however, it will decline when adding fermentation periods.

High quality of starch is characterized by an increase of starch content and produced pasta contains a low solubility, an increased volume and swelling power. The high solubility and low swelling volume show a low quality of starch because of a dilute solution and unstable pasta when it is cooked (Leach and Scoch, 1996; Afoawka and Aidoo, 2005). The strength of swelling volume and solubility of starch indicates covalent bonds between starch molecules. The ratio between amylosaamylopectin, long chains and distributing molecule weights, conformation and degree of branched molecules play an important role in swelling volume and solubility
(Moorthy, 2001). The high amylosa and tied intramolecular contents will reduce swelling volume.

\section{Gelatinization profiles}

A gelatinization profile of starch varies in granular characteristics and this indicates the prediction of functional properties and applicable potencies. Some changes are discovered along heating water-starch such as swelling volume, an increase of viscosity, tranlusen, solubility and loosing birefringence, the changes is called gelatinization.

The high initial gelatinization temperature indicates resists granules to be enlarged. One of pasta 


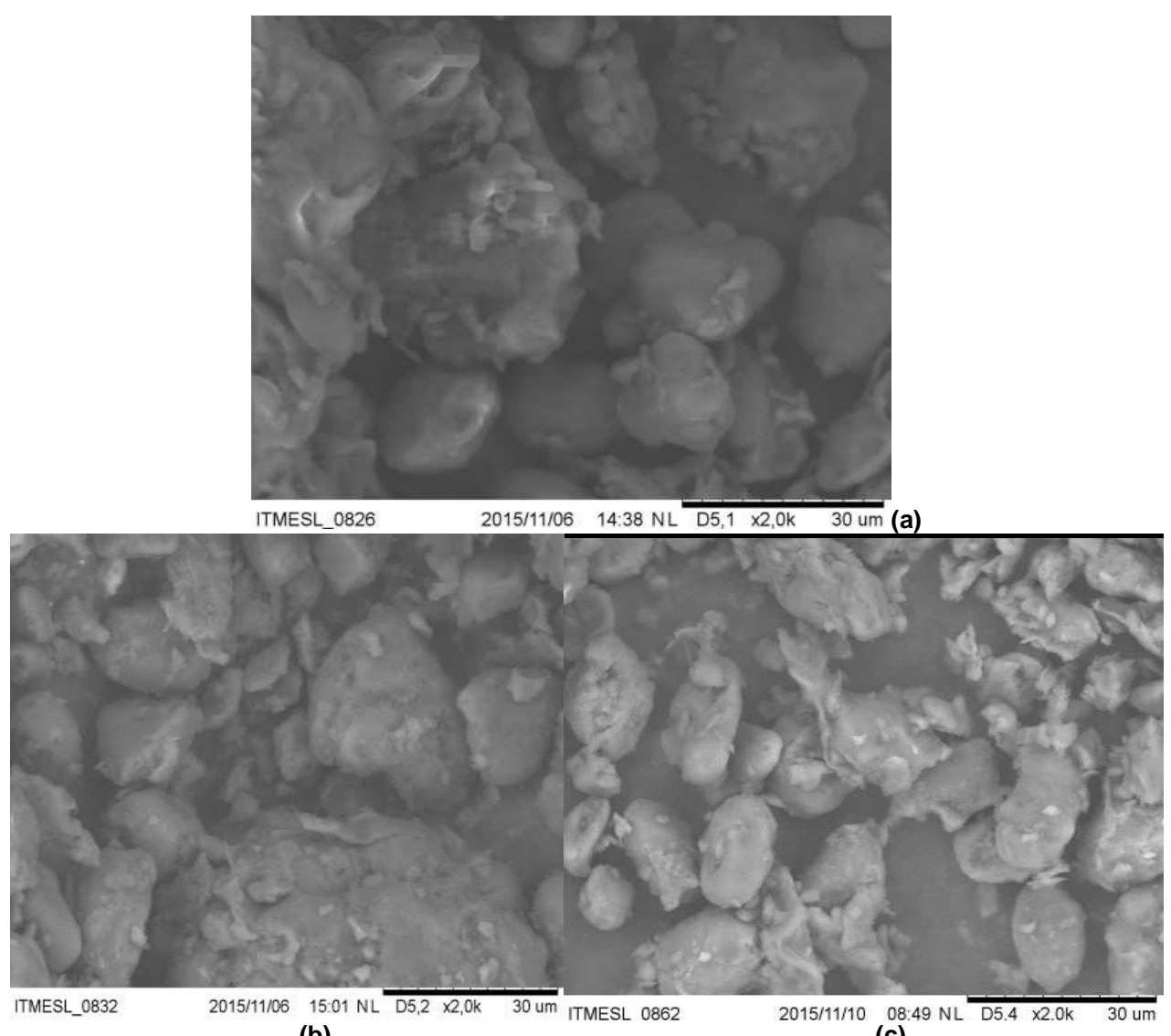

(b)

(c)

Figure 3. Scanning electron Microscopy (SEM) of granula in 2,0k $\times 30 \mu \mathrm{m}$ a) control; b) whole sizefermented flour by L.plantarum; c) ) grits size-fermented flour byL. Plantarum

characteristics, pasta temperature, shows a minimum temperature to cook, energy costs and other stability of components. Peak viscosity indicates the characteristics of starch bonded water. Final viscosity is defined starch qualities, stability of products, and ability of formed pasta or gel after cooling periods. Gelatinization profiles of Nagara bean flour is described in Table 2 and Figure 1 and 2.

Gelatinization profiles of fermented Nagara bean flour were higher than the control and the fast result was showed for 48 hours of fermentation and grits size. These characters were caused by enzymes from LAB and a high lactic acid triggering the changes of starch.

Peak viscosity is the ability of starch to swell before physical changes happens (Sanni et al. 2004). The high peak viscosity of Nagara bean flour was noted for 48 hours fermentation and grits size showing $2713 \mathrm{cP}$ (226.08 RVU). Based on Osungbaro (1990), the high value of peak viscosity indicated the high starch contents and related to water bonded starch capacities (Adobewale et al. 2005), then starch content of spontaneous fermented Nagara bean flour was around $50.13-71.97 \%$ db (Susi et al. 2015). Having high peak viscosity of Nagara bean flour is suitable for some products needing high gel powers and elastic. Holding viscosity is the minimum value of stable temperatures and used to measure pasta from the breakdown along cooling periods, with the top trough value $1326 \mathrm{cP}$ (110.5 RVU) from fermented Nagara bean flour for 48 hours fermentation and grits size.

Fernande and Berry (1989) stated the stability of starch from breakdown viscosity. The value of breakdown viscosity was $708-1396 \mathrm{cP}(59-116.33 \mathrm{RVU})$. Final viscosity indicated viscosity changes after $50^{\circ} \mathrm{C}$ with the value of 1668 - 2906 cP $(139-242.17$ RVU). Final viscosity is generally used to determine quality of starch products forming viscous pasta or gel after cooking and cooling periods and in line with a resist pasta from friction along stirring.

Pasta temperature did not significantly differ from the control with the value of $78^{\circ} \mathrm{C}$. Eniola dan Delarosa (1981)stated that pasta temperatures indicated time of a gelatinization process which meant an increase of viscosity for the first time and an early changing index due to swelling of starch. Pasta temperatures were related to water binding capacity that an increase of 
temperature had results of high water binding capacities, of high gelatinization processes and of low swelling volume starch due to an increase in association levels of granular starch(Eniola and Delarosa, 1981; Numfor et al. 1996).

Legume starch had implied high viscosity rather than grain flour (Lineback and Ke 1975) that meant legume starch more resistant in terms of swelling and friction. The structure and size of granular starch, a degree of crystallization, protein and fat, a size of molecule and a number of branches in starch fraction influenced viscosity (Schoch and Maywald 1968). In addition, gelatinization processes was affected by starch types, granular sizes, concentration, ratio between amylosa and amylopectin, an endogen component such lipid and other additional materials. Susi et al. (2015) discovered level of amylosa in non fermented Nagara bean flour was lower than in fermented one using $L$. plantarum which was around $20.5 \%$ and $20.66 \%-26.96 \%$ respectively. The finding indicated fermented Nagara bean flour having a high temperature of gelatinization processes.

An average of protein content in fermented Nagara bean flour was $20.5 \%$ that interrupting the process of enlarged granular starch and reducing viscosity (Hamaker and Griffin 1993; Yang and Chang 1999). Lipid and protein contents have formed inclusion complexes of amylose in native starch and flour causing decrease in rate of swelling.

Interaction between protein and starch was caused by different charges of molecule bonds and then forming inclusion complexes during gelatinization processes disturbed swelling process. Amylosa functions as diluents and inhibitors swelling processes particularly when available lipid triggered non dissolved complexes to amylosa. Starch molecule has hydrogen bonds in crystal bundle forms influencing granular bonds during swelling processes and solubility (Leach et al. 1959). When granular starch was heated, its structure would be hydrated and increased for high swelling, moderate swelling, restricted swelling or highly restricted swelling. Crosslink happened in granular starch would reduce swelling and stabilize the friction (Galves and Resurreccion 1993).

\section{Scanning electron microscopy (SEM)}

Physical and chemical changes of fermented flour can be seen from its structure. In general, fermented flour will lose the soft structure of flour. Adding microbial starter will form irregular structures. Scanning electron microscopy of granular starch in grits size shows smaller size and irregular structure compared to granular starch in whole size. Granular starch in a spontaneous fermentation process and in lactic acid bacteriacould be seen in Figure 3.
Figure 3 describes a small damaged level of granules; however, fermented flour both whole and grits sizes shows intensive damage. Moreover, degree of damaged granules randomly happens not in all surface of its structure.

\section{CONCLUSION}

Fermented Nagara bean flour by L. plantarum showed better water absorption, swelling volume and gelatinization characteristics along 48 hours fermentation and in grits size compared to the control. Grits sizes provided faster changing rather than whole sizes and time of fermentation by L. plantarum.

\section{ACKNOWLEDGEMENT}

The authors would thank to DP2M DIKTI for the finance through Hibah Pekerti in the year of 2015.

\section{REFERENCES}

Adebowale AA, LO Sanni, SO Awonorin. (2005). Effect of texture modifiers on physicochemical and snsory properties of dried fufu. Food Sci Technol. Int. 11:373-382

Afoakwa EO, Aidoo R (2005). Changes in souring development, nutritional and functional properties during fermentation of cowpeafortified nixtamalized maize. Inter J Food Sci Nutr 61: 256-271.

Atuobi C, Sakyi-Dawson E, Sefa-Dedeh S, Afoakwa EO, Budu AS. (2011). Microstructural and Physico-Functional Characterization of Starches from Selected Cowpea (Vigna unguiculata L. Walp.) Varieties Developed for Pest and Disease Resistance. J Nutr Food Sci 1:104.

Chinsamran K, Piyachomkwan K,Santisopasri V, Sriroth K. (2005). Effect of Lactic Acid Fermentation on Physico-chemical Properties of Starch Derived from Cassava, Sweet Potato and Rice. Thailand

Eniola L, LC Delarosa. (1981). Physicochemical characterizes of yam starches. J. Food Biochem. 5:115-130

Etudaiye HA, Nwabueze, TU, Sanni, LO. (2009). Quality of fufu Processed from Cassava Mosaic Diease (CMD) Resistant Varietier. African Journal Of Food Science 3 (3):061-067

Femande De Tonella ML, JW Berry. (1989). Rheological properties of flour and sensory characteristics of bread made from germinated chick peas. Internal. J. Food Sci.Technology

Galvez FCF, Resurreccion AVA(1993). The effects of decortication and method of extraction on the physical and chemical properties of starch from mung bean (Vignaradiate (L.) wilczec). Journal of Food Processing and Preservation, 17: 93-107.

Hamaker BR, Griffin VK. (1993) Effect of disulfide bond-containing protein on rice starch gelatinization and pasting. Cereal Chemistry, 70:377-380.

Leach HW, McCowen LD, Schoch TJ(1959). Structur of the Starch Granule. 1. Swelling and solubility patterns of various starches. Cereal Chem. 36:534-544

Leach HW, Schoch TJ. (1996). Structure of the starch granule II. Action of the various Amylases on Granular Starches. Cereal Chem38: 3446.

Lineback DR, Ke $\mathrm{CH}(1975)$. Starches and low-molecular -weight carbohydrates from chick pea and horse bean flours. Cereal Chemistry, 52:334-347.

Moorthy SN . (2001). Tuber crop starches in Central Tuber Crops Research Institute. 2nd Edition. St Joseph's Press. India. 18: 42. 
Niba L. (2003). The relevance of biotechnology in the development of functional foods for improved nutritional and health quality in developing countries African Journal of Biotechnology 2 (12): 632635

Numfor FA, WM walter, SJ Schawrtz. (1996). Effect of emulsifiers on the physical properties of native and fermented cassava starches. J. Agric. Food Chem. 44:2595-2599

Olapade AA, OB Oluwole, OC Aworh(2012). Physico-chemical properties and consumer acceptance of instant cowpea (Vigna unguiculata) powder for complementary food. African J. Food Sci. Technol., 3: 102-106

Osungbaro TO (1990). Effect of differences in variety and dry milling of maize on texture characteristics of ogi. J. Food. Agric. 54:1-11

Sanni LO, Kasoko AA, Adebowale RJ Adeoye.( 2004). The Influence of palm oil anf chemical modification on the pasting and sensory properties of fufu flour. Int. J.Food Properties, 7:229-237
Schoch TJ, Maywald EC(1968). Preparation and properties of various legume starches. Cereal Chemistry, 45:564-573.

Susi S ( 2012). Komposisi Kimia dan Asam Amino Tempe Kacang nagara. Agroscientiae 19 (1) p 28-36

Susi S ( 2015). Modifikasi Tepung Kacang Nagara Melalui Fermentasi Bakteri Asam Laktat untuk Produksi Beras Analog Dalam Rangka Ketahanan Pangan. Laporan Penelitian. Banjarbaru

Tester, RF,WR Morrison (1990). Swelling and Gelatinization of Cereal Starches. II Waxy Rice Starches. Cereal Chem. 67(6):558-563

Thangadurai D. (2005). Chemical Composition And Nutritional Potential Of Vigna Unguiculatassp.Cylindrica (Fabaceae). J. Bichem. $29: p$ 88-98

Yang $\mathrm{CH}$, Chang WH. (1999). Effects of protein and lipid binding to starch on the physicochemical and pasting properties of rice flour. J. Food Sci. and Agric. Chem., 1: 277- 285. 